\title{
Influence of Finishing/Polishing in Surface Roughness of Conventional Nanocomposites and Bulk-Fill
}

\section{Influência do Acabamento/Polimento na Rugosidade de Superfície das Resinas Compostas Nanoparticuladas Convencional e Bulk-Fill}

\author{
Carlos Frederico Bettcher Silva*a; Gabriel Batista de Souza ${ }^{\mathrm{a}}$; Luan Miranda Moria ${ }^{\mathrm{a}}$, Ricardo Huver de Jesus ${ }^{\mathrm{b}}$; Jefferson \\ David Melo de Matos ${ }^{\mathrm{c}}$; Lucas Campagnaro Maciel ${ }^{\mathrm{d}}$

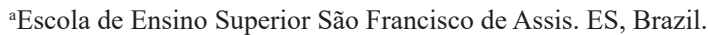

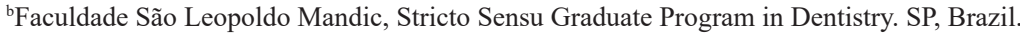 \\ 'Universidade Estadual Paulista, Stricto Sensu Post-Graduate Program in Restorative Dentistry. SP, Brazil. \\ ${ }^{\mathrm{d}}$ Faculdade Multivix. ES, Brazil. \\ *E-mail: fredericobettcher@hotmail.com
}

\begin{abstract}
The choice of the best finishing/polishing methods for composite resin restorations is critical to the choice of excellence results related to longer clinical longevity. The objective of the study was to evaluate the influence of finishing and polishing systems on the surface roughness of a Nanoparticulate and Bulk-fill resin. For the research, 40 sample disks were prepared for each composite: single-increment (BF) (Bulk Fill 3M), both $2 \mathrm{~mm}$ thick and $10 \mathrm{~mm}$ in diameter (FZ) (Filtek Z350,3M). The specimens were randomly divided into 4 groups with 10 samples each, according to the different materials to which they were subjected to the finishing and polishing protocols: control [C]- diamond tip (FG 4137F FAVA); [EN] polishing discs (Enhance, Dentsply); [SL] Abrasive discs (Sof-Lex Pop-on, 3M) and [PD] felt disc + Polishing paste (Diamond Excel, FGM). A surface roughness ( $\mathrm{Ra}$ ) was verified with a roughness meter in three different data volumes and calculated as arithmetic means. Data were statistically treated by one way ANOVA followed by test $t$ and student $t$ test. Regardless of the data tested, evidence of the systemic controlling against different systems for polishing control with control $(\mathrm{p}<0.05)$. PD presented statistically greater roughness to the EN and SL $(p<0.001)$, these in turn obtained similar performance and presented the lowest values of roughness for both composites ( $p>0.05)$. The different finishing / polishing methods influenced the surface roughness of both composites, observing for Sof-lex and Enhance lower Ra values.
\end{abstract}

Keywords: Nanoparticles. Dental Polishing. Composite Resins.

\section{Resumo}

A escolha dos adequados métodos de acabamento/polimento para restaurações de resina composta é fundamental para obtenção de resultados de excelência, relacionados a maior longevidade clínica. O objetivo desse estudo foi avaliar a influência dos sistemas de acabamento e polimento na rugosidade de superficie das resinas nanoparticuladas convencional e bulk-fill. Para a pesquisa foram confeccionados 40 discos de amostra para cada compósito: Convencional [FZ] (Filtek Z350, 3M) e de incremento único [BF] (Filtek Bulk Fill, 3M), ambas com $2 \mathrm{~mm}$ de espessura e $10 \mathrm{~mm}$ de diâmetro. Foram divididos aleatoriamente em 4 grupos com 10 amostras cada, de acordo com os diferentes protocolos que receberam, sendo: controle (C) ponta diamantada (FG 4137F, FAVA); (EN) discos de silicone (Enhance, Dentsply); (SL) discos abrasivos (Sof-Lex Pop-on, 3M); (PD) Feltro + Pasta diamantada (Diamond Excel, FGM). A rugosidade de superficie (Ra) foi verificada com um rugosímetro em três leituras de diferentes direções e calculadas as médias aritméticas. Os dados foram tratados estatisticamente pelos testes ANOVA 1 fator seguido pelo teste te $t$ de student $(p<0,05)$. Independente da resina testada, evidenciou-se diminuição da rugosidade pelos diferentes sistemas de polimento frente ao grupo controle $(p<0,05)$. PD apresentou rugosidade estatisticamente maior à EN e SL $(p<0,001)$, estes últimos que por sua vez obtiveram desempenho semelhante e apresentaram os menores valores de rugosidade para ambos os compósitos $(p>0,05)$. Os diferentes métodos de acabamento/polimento influenciaram na rugosidade de superfície dos dois compósitos testados, observando para Sof-lex e Enhance menores valores de Ra.

Palavras-chave: Nanopartículas. Polimento Dentário. Resinas Compostas.

\section{Introduction}

Currently, composite resins constitute a class of dental material with diverse clinical applicability, widely used in previous and subsequent direct restorations for presenting satisfactory mechanical and esthetic properties ${ }^{1,2}$. In addition, it is a composite that constantly evolves along with techniques that aim to improve the result making it more efficient with every new discovery ${ }^{3}$. With the advent of nanotechnologies, this material was submitted to alterations in its inorganic portion, reducing the size of the load particles to a scale of approximately $0.75 \mathrm{~m}$ and adding them proportionally in its composition, thus resulting in nanoparticles resins ${ }^{4,5}$. This fact reduces polymerization contraction and consequently increases wear resistance by also providing higher quality during polishing, resulting in improvements in optical properties $^{4,6,7}$.

Single-fill or bulk-fill resins appear on the market as an alternative for extensive subsequent restorations, due to the possibility of working with relatively large increments of approximately $4-5 \mathrm{~mm}^{8,9}$. The low degree of contraction presented as a result of polymerization is what makes it possible to use this technique, making secondary properties as 
a cavitary configuration factor (factor $\mathrm{C}$ ) and the incremental technique that are both diffused among the conventional resins ${ }^{10-14}$.

However, a rough and shapeless surface may cause a greater biofilm accumulation, secondary caries, periodontal problems and short-term chromatic alterations ${ }^{15-17}$. Thus, finishing appears at first, improving the anatomical form to the restored structure, and the polishing procedures aiming to reduce the roughness resulting from previously performed procedures, such as the use of burs on the surface ${ }^{5,18}$. Thus, the lower the roughness values, the better the relationship between restoration and adjacent tissues, being directly related to the durability of the same $e^{7,19-21}$.

Before the various types of materials available on the market for resins finishing and polishing, it is known that the use of these resources promotes variations in flatness according to the types of composites to which they have been submitted to such procedures ${ }^{20}$. Thus, the objective of this study is to evaluate the influence of different finishing/ polishing methods on the surface roughness of conventional nanoparticles and bulk-fill composite resins, being such resins widely used in modern dentistry. The null hypotheses tested were: (1) Polishing will not influence the resins surface roughness (conventional and bulk-fill) and (2) conventional nanoparticulate and bulk-fill resins will not show any difference in roughness when submitted to the same finishing/ polishing systems.

\section{Material and Methods}

40 discs of the sample for each composite were made: Conventional Nanoparticulate (Filtek Z350 XT 3M ${ }^{\text {TM }}$ ESPE ${ }^{\text {TM }}$, St. Paul, MN, USA) and single increment (Filtek ${ }^{\text {TM }}$ Bulk Fill posterior Restorative $3 M^{\text {TM }}$ ESPE ${ }^{\text {TM }}$, St. Paul, MN, USA) (Table 1), $2 \mathrm{~mm}$ thick and $10 \mathrm{~mm}$ diameter.

Table 1 - Composites used

\begin{tabular}{|c|c|c|c|c|}
\hline Group & Manufacturer & Organic Matrix & Load Content & $\begin{array}{l}\text { \% Load Weight } \\
\text { \%/ Load Volume }\end{array}$ \\
\hline $\begin{array}{l}\text { Filtek } \\
\text { Z350 } \\
(\mathrm{FZ})\end{array}$ & 3M ESPE & $\begin{array}{l}\text { BisGMA, UDMA, } \\
\text { TEGDMA, BisEMA, } \\
\text { PEGDMA }\end{array}$ & $\begin{array}{l}\text { Combination of Silica } 20 \mathrm{~nm} \text { (non-agglomerated/ non- } \\
\text { aggregated), zirconia } 4-11 \mathrm{~nm} \text { (non-agglomerated/ non- } \\
\text { aggregated) and agglomerates of zirconia/silica of } 0.6 \\
-10 \mu \mathrm{m}\end{array}$ & $78.5 \% / 63.3 \%$ \\
\hline $\begin{array}{l}\text { Filtek } \\
\text { Bulk-fill } \\
\quad(\mathrm{BF})\end{array}$ & 3M ESPE & $\begin{array}{l}\text { BisGMA, } \\
\text { BisEMA, } \\
\text { UDMA, TEGDMA }\end{array}$ & $\begin{array}{l}\text { Combination of Silica 20nm (non-agglomerated/ non- } \\
\text { aggregated), zirconium 4-11nm (non-aggregated), } \\
\text { zirconium/silica aggregate (containing particles of } 20 \mathrm{~nm} \\
\text { of silica and zirconium } 4-11 \mathrm{~nm} \text { ) and ytterbium trifluoride } \\
\text { fill in } 100 \mathrm{~nm} \text { agglomerate particles. }\end{array}$ & $76.5 \% / 58.5 \%$ \\
\hline
\end{tabular}
*Bis-GMA: Bisphenol-A-ether glycidil dimethacrylate; Bis-EMA: bisphenol-A glycidil dimetacriside ethoxylated; TEGDMA: Triethylene glycol dimethacrylate; UDMA: Dimethacrylate urethane; PEGDMA: Polyethylene Di methacrylate glycol.

Source: Research data.

The specimens were randomly divided into 4 groups with 10 samples each according to the different finishing and polishing systems they received (Table 2).

Table 2 - Group distribution according to material to be used for finishing/polishing

\begin{tabular}{|c|c|c|c|}
\hline Group & Material & Brand & Composition \\
\hline Group C & $\begin{array}{c}\text { Diamond tip round top } \\
\text { conical trunk FG 4137 } \\
\text { F. }\end{array}$ & $\begin{array}{c}\text { Metalúrgica FAVA. } \\
\text { Ind. Com. Ltda, } \\
\text { Pirituba, SP, BR. }\end{array}$ & $\begin{array}{c}\text { Stainless steel rod and active part formed by natural and } \\
\text { synthetic micro-grains of diamonds fixed by galvanic process. }\end{array}$ \\
\hline PD Group & $\begin{array}{c}\text { Diamond Flex felt disc } \\
+ \text { Diamond Excel } \\
\text { polishing paste. }\end{array}$ & $\begin{array}{c}\text { FGM, São Paulo, SP, } \\
\text { Brazil. }\end{array}$ & $\begin{array}{c}\text { Polyester disc, adhesive, microbristels and silicone rubber/ } \\
\text { Micronized Diamond of extra-fine granulation and very high } \\
\text { hardness, lubricant, thick and emulsifying base. }\end{array}$ \\
\hline SL Group & $\begin{array}{c}\text { Silicone polishing discs } \\
\text { for resins finishing } \\
\text { (Enhance System). }\end{array}$ & $\begin{array}{c}\text { Dentsply Sirona } \\
\text { Brazil, São Paulo, SP, } \\
\text { BR. }\end{array}$ & $\begin{array}{c}\text { Tripolymer, Silanized Pyrolytic Silica, Dimetacrylate Urethane, } \\
\text { Camphorquinone, N-Methyl Diethanolamine and Aluminum } \\
\text { Oxide. }\end{array}$ \\
\hline Source: Research data. & $\begin{array}{c}\text { Abrasive discs (Sof- } \\
\text { Lex Pop-on). }\end{array}$ & $\begin{array}{c}\text { 3M do Brasil Ltda, } \\
\text { Sumaré, SP, BR. }\end{array}$ & Cured urethane support, Aluminum oxide grains and binder. \\
\hline
\end{tabular}

\subsection{Samples preparation}

Using a $2 \mathrm{~mm}$ deep, $10 \mathrm{~mm}$ diameter silicone matrix, a single operator previously trained manually performed the sample making process. Conventional Nanoparticulate resin (Filtek Z350 XT 3M ${ }^{\text {TM }}$ ESPE ${ }^{\text {TM }}$, St. Paul, MN, USA) and the bulk-fill resin (Filtek ${ }^{\text {TM }}$ Bulk Fill Posterior Restorative $3 M^{\text {TM }}$ ESPE ${ }^{\text {TM }}$, St. Paul, MN, USA) were inserted in the matrix by a single increment, both with the aid of a stainless steel spatula Suprahill \#1 (Golgran Ind. Com. Instr. Odontológicos, São Caetano do Sul, SP, BR). The filled matrix has been fixed in the center of a glass plate and covered with a polyester strip. Then a glass blade was positioned on the polyester matrix together with a weight of $1 \mathrm{~kg}$ for 30 seconds to obtain a flat surface and contents of the homogeneous matrix. The weight 
was then removed and the sample was light-cured with Bluephase N ligth-curing unit (Ivoclar Vivadent, Barueri, SP, $\mathrm{BR}$ ) was removed through the glass plate and polyester strip with a power of $1200 \mathrm{~mW} / \mathrm{cm}^{2}$ for a time of 20 seconds. Soon after, the samples were immersed in distiled water at $37{ }^{\circ} \mathrm{C}$ for 24 hours.

\subsection{Resin discs inclusions}

After the samples were prepared, they were placed on a dental wax blade number 7 (Lysanda Produtos Odontológicos, São Paulo, SP, Brazil) and then a cylindrical PVC matrix (Tigre Tubos e conexões, Rio Claro, São Paulo, Brazil) with a diameter of $25 \mathrm{~mm}$ and a height of $10 \mathrm{~mm}$ was adapted around each composite resin sample. Then, a colorless self-polymerizable acrylic resin (Jet - Clássico Artigos Odontológicos, São Paulo, SP, Brazil) was provided and manipulated according to the manufacturer's instructions and, in its plastic phase, poured into the PVC matrix. With the complete polymerization, the best specimens manipulation was made possible, facilitating and making it possible the surface treatment procedures and the roughness test.

\subsection{Samples standardization}

In order to ensure the standardization of the specimens, all the samples were submitted to the polishing machine Metalprisma ERIOS Equipamentos Eireli, São Paulo, SP, Brazil) at 300rpm, with 4 lbs of weight and wet sand paper of granulation \#, 400 \#600 and \#1200(Norton Abrasivos Ltda, São Paulo, SP, Brazil) for 15 seconds each. Soon after, they were sprinkled with rounded top conical trunk bur FG 4137F (Metalúrgica FAVA. Ind. Com. Ltda, Pirituba, SP, Brazil) attached to the straight piece at low rotation Kavo 500 (Kavo Dental GmbH, Berlin, Germany) under intermittent water spray for 15 seconds in back and forth soft pressure movements over the sample surface. Then, they were washed for 10 seconds with spray (air/water) and dry. Each bur was discarded after use in 5 samples. Thus, it was possible to guarantee the surfaces standardization prior to the procedures performed.

\subsection{Finishing and polishing procedures}

After the samples preparation as mentioned above, the specimens were randomly distributed between the preestablished groups. For each type of composite (conventional nano-particle and bulk-fill), 10 samples were intended for each group of finishing and polishing procedures, which were performed by a single operator previously trained as follows:

- C group [control] (diamond tip): The samples for this group were not given any procedure other than the one already mentioned and performed (conditioning with polishing machine and finishing with round-top conical trunk bur FG 4137F).

- $\quad$ PD group (diamond paste): The samples aimed at this group received polishing procedure usingDiamond Flex felt disc (FGM, São Paulo, SP, Brazil.) + Diamond Excel Polishing
Paste (FGM, São Paulo, SP, Brazil) coupled to low-rotation counter Kavo 500 (Kavo Dental GmbH, Berlin, Germany) following the soft planing protocol of the surface for 30 seconds. Soon after, they were washed for 10 seconds with spray (air/water) and dry. Each disk was discarded after use in a sample.

- EN Group (Enhance system): Samples intended for this group underwent polishing procedures using silicone Enhance discs (Dentsply Sirona Brasil, São Paulo, SP, BR) coupled to a low-rotation counter angle Kavo 500 (Kavo Dental GmbH, Berlin, Germany) following the soft planing protocol of the surface for 30 seconds. Soon after, they were washed for 10 seconds with spray (air/water) and dry. Each disc was discarded after use in 2 samples.

- SL group (SOF-lex system): The samples aimed at this group underwent polishing procedures by means of abrasive discs Sof-Lex Pop-on (3M do Brasil Ltda, Sumaré, SP, BR) in orange, beige and yellow colors (medium, fine and extra fine granulation, respectively) coupled to counter angle in low rotation Kavo 500 (Kavo Dental GmbH, Berlin, Germany) following the mild planing protocol of the surface for 10 seconds on each disc. Soon after, they were washed for 10 seconds with spray (air/water) and dry. Each disc was discarded after use in 2 samples.

After all finishing/polishing procedures were completed, the samples were immersed in ultrasonic bowl (Cristofóli Biossegurança, Campo Mourão, PR, Brasil) for 180 seconds to thoroughly remove debris from exposed procedures.

\subsection{Surface roughness test}

Three readings were performed in different directions of the samples using the Surftest SJ-310 series 178 roughness meter (Mitutoyo Corporation, Kawasaki, Kanagawa, Japan), then the arithmetic mean was calculated between them and stored in suitable database in Microsoft Excel 2016 software (Microsoft Corporation, Redmond, WA, USA).

\subsection{Statistical analysis}

The data were statistically analyzed using Bioestat 5.0 software (Bioestat, Maringá, PR, BR). Kolmogorov-Smirnov tests were performed for normality analysis and then the ANOVA 1-factor test and t test were applied for comparative analysis of the different finishing/polishing systems. Student's t-test was used to compare the two different composites when submitted to the same finishing/polishing systems and was adopted for comparisons $\mathrm{p}<0.05$.

\section{Resultand Discussion}

Table 3 shows the mean values and the standard deviations of surface roughness (Ra) of the different treatments performed in each tested composite. In both resins, the finishing/polishing procedures influenced (decreased) surface roughness when compared to the control group. Higher values of $\mathrm{Ra}$ are observed in $\mathrm{PD}$ when compared to groups $\mathrm{SL}$ and EN, however, lower compared to $\mathrm{C}$ group $(\mathrm{p}<0.001)$. In addition, lower Ra values are observed when using the abrasive discs SOF-Lex (SL) and Enhance (EN) with no statistically significant differences between both when 
compared to groups $\mathrm{C}$ and $\mathrm{PD}(\mathrm{p}<0.001)$.

Table 3 - Surface roughness (Ra) of resins after finishing/ polishing

\begin{tabular}{|c|c|c|c|}
\hline Resin & Groups & Roughness $(\boldsymbol{\mu})$ & p value \\
\hline & Control (C) & $0.961 \pm 0.098^{\mathrm{A}}$ & \\
\hline $\begin{array}{c}\text { Z350 } \\
(\text { FZ) }\end{array}$ & $\begin{array}{c}\text { Diamond paste } \\
(\mathrm{PD})\end{array}$ & $0.355 \pm 0.036^{\mathrm{B}}$ & \\
\hline & Enhance (EN) & $0.187 \pm 0.013^{\mathrm{C}}$ & $\mathrm{p}<0.001$ \\
\hline & Sof-Lex (SL) & $0.158 \pm 0.024^{\mathrm{C}}$ & \\
\hline $\begin{array}{c}\text { Bulk-fill } \\
\text { (BF) }\end{array}$ & $\begin{array}{c}\text { Diamond paste } \\
\text { (PD) }\end{array}$ & $0.401 \pm 0.059^{\mathrm{B}}$ & \\
\hline & Enhance (EN) & $0.214 \pm 0.046^{\mathrm{C}}$ & $\mathrm{p}<0.001$ \\
\hline & Sof-Lex (SL) & $0.179 \pm 0.064^{\mathrm{C}}$ & \\
\hline
\end{tabular}

Tests ANOVA 1 FACTOR and t test* Distinct vertical letters denote statistical difference $(\mathrm{p}<0.05)$.

Source: Research data.

Table 4 compares the mean values and the standard deviations of Ra between the composites when submitted to the same surface treatments. Groups $\mathrm{C}$ and PD of FZ composite presented lower roughness values when compared to the same groups (C and PD) in BF, showing a statistically significant difference between them $(\mathrm{p}<0.05)$. However, for SL and EN, no statistically significant differences were observed between the different composites ( $\mathrm{p}>0.05)$.

Table 4 - Comparison of Surface roughness (Ra) of resins after finishing/polishing

\begin{tabular}{|c|c|c|c|c|}
\hline Resin & \multicolumn{4}{|c|}{ Finishing/Polishing. } \\
\hline $\begin{array}{c}\text { Control } \\
\text { (C) }\end{array}$ & $\begin{array}{c}\text { Diamond } \\
\text { paste (PD) }\end{array}$ & $\begin{array}{c}\text { Enhance } \\
(\mathrm{EN})\end{array}$ & $\begin{array}{c}\text { Sof-lex } \\
(\mathrm{SL})\end{array}$ & \\
\hline Z350 & $0.961 \pm$ & $0.355 \pm$ & $0.187 \pm$ & $0.158 \pm$ \\
(FZ) & $0.098^{\mathrm{A}}$ & $0.036^{\mathrm{A}}$ & $0.013^{\mathrm{A}}$ & $0.024^{\mathrm{A}}$ \\
\hline Bulk-fill & $1.227 \pm$ & $0.401 \pm$ & $0.214 \pm$ & $0.179 \pm$ \\
(BF) & $0.068^{\mathrm{B}}$ & $0.059^{\mathrm{B}}$ & $0.046^{\mathrm{A}}$ & $0.064^{\mathrm{A}}$ \\
\hline p value & $<0.0001$ & $=0.0496$ & $=0.991$ & $=0.3574$ \\
\hline
\end{tabular}

t-Student tests. *Distinct vertical letters denote statistical difference $(\mathrm{p}<0.05)$.

Source: Research data.

Proper completion of the finishing/polishing step is essential for obtaining clinical results of excellence of direct restorations in composite $\operatorname{resin}^{7,19,21}$. The failure of this process directly affects the longevity of the composites used, as they result from other problems in the bacterial biofilm retention, chromatic alterations, discomfort, and consequent dissatisfaction by the patient $\mathrm{t}^{15-17,20}$.

In this context, the present study aimed at evaluating the influence of different polishing systems on the surface roughness of two composites. According to the results presented, the first null hypothesis tested was rejected, since the polishing procedures (PD, EN, SL) influenced the Ra values when compared to the control group.

Thus, these findings corroborate with the research of Gönülol, Yilmaz ${ }^{22}$, who verified in their study higher values of roughness in nanocomposites when using diamond burs before other polishing systems, this fact can be explained by the arrangement and hardness of the metallic-based diamond fragments of these burs, which by friction during the finishing procedure can cause the inorganic load particles of the resin to move, thus exposing a surface of greater irregularity. Ehrmann et al. ${ }^{17}$ suggest that, after using these burs, an additional step is always used for polishing, aiming at obtaining greater surface flatness, a condition reinforced by the present research.

For PD group (felt disc + diamond paste), it is noted that this system considerably reduced the surface roughness left by the diamond tip, possibly because it has high hardness micronized abrasive diamond grains, wearing the particles that were exposed irregularly ${ }^{15}$. Just as in the current research, the findings of Martins Alves et al. ${ }^{15}$ and Bittencourt et al. ${ }^{23}$ also confirmed the influence of this polishing mechanism on the roughness of compound resins, visualizing a decrease in Ra values when used on rough surfaces. In contrast, Costa et al. ${ }^{2}$ suggest that the use of diamond paste in composite resins may be of value when used later on for instruments with aluminum oxide in the composition, in the case of this study, present in Sof-Lex and Enhance.

Therefore, these aluminum oxide particles have as their characteristic superior hardness the load particles incorporated in the inorganic matrix of the composites, thus favoring the realization of more even wears, exposing a homogeneous layer of high superficial flatness ${ }^{3}$. Previous studies carried out by Yadav et al. ${ }^{18}$, Gönülol and Yilmaz ${ }^{22}$, Alves et al. ${ }^{24}$, obtained results that converge with the current work, also verifying the similarity of performance betweenSof-lex and Enhance, possibly due to the presence of aluminum oxide in both compositions and their above mentioned characteristics.

The second null hypothesis tested was also rejected, since groups $\mathrm{C}$ and PD presented statistically significant differences when compared between the Filtek Z350 and Filtek bulk-fill resins $(\mathrm{p}<0.05)$ (Table 4$)$.

Furthermore, despite having similar constitutions, the single-fill composite used in this study has $2 \%$ less inorganic loading weight and 5\% less volume compared to the nanoparticle resin, which, after the use of a bur, as well as of felt + diamond paste, they may have resulted in a surface with greater irregularities when compared to Filtek Z350, which, due to its greater volume and load weight, probably presents greater homogeneity and reduction of interstitial space, exposing the surfaces with greater smoothness observed in the face of submission to the systems cited ( $C$ and PD).

The superior polishing capacity in conventional composite nanoparticles is reported in the literature by several authors and is related to similar properties of the present study $y^{3,18,24}$. Thus, these findings also converge with the studies by Maddy et al. ${ }^{5}$ and Rigo et al. ${ }^{11}$, who verified such interrelation between the different compositions of composite resins and the polishing capacity according to the systems used. However, no significant differences were observed between the groups $\mathrm{EN}$ and SL when compared between the composites FZ and BF ( $>0.05)$, results that are found with those of De Almeida 
et al. ${ }^{9}$ who viewed similar behavior between Filtek Z350 and Filtek bulk-fill polished with SOF-lex, probably due to the presence of aluminum oxide incorporated into this system and the similar composition of both resins.

In addition to the above, surface roughness values of compound resins are considered acceptable when inserted in the range between $0.7 \mu \mathrm{m}-1.44 \mu \mathrm{m}^{3,5,25}$. Thus, none of the systems adopted in the current study demonstrated Ra values considered intolerable. However, some authors state that values above approximately $0.2 \mu \mathrm{m}$ will result in retention of bacterial biofilm ${ }^{16,18}$. Thus, $\mathrm{C}$ and PD groups of both composites exposed values above this threshold, as well as EN of BF. Authors such as Martins Alves et al. ${ }^{15}$ and Sahbz et al. ${ }^{20}$ expose that, when values of approximately $0.4 \mu \mathrm{m}$ are exceeded, roughness can be clinically observed by the patient, so this could be verified in $\mathrm{C}$ groups of both composites, as well as in PF of BF.

In general, considering the comparison between the group that simulated the finishing procedure $(C)$ and the others that, in addition to the use of burs, were submitted to different polishing procedures (PD, EN and SL), it is observed that all of them influenced the decrease in roughness, demonstrating the systems effectiveness. Also, SOF-Lex and Enhance presented better Ra values, corroborating with other studies that indicate aluminum oxide particles as the most effective for polishing of compound resins $s^{2,3,18,22,24}$. However, since this is an in vitro study, the results should not be extrapolated to clinical practice without considering the limitations of the present study. Moreover, the need to elaborate further laboratory research aimed at discussing the polishing methods for the different composites is affirmed, making it possible to find results that support the indications and condiderations regarding their use.

\section{Conclusion}

Through the proposed methodology and the exposed results, it can be concluded that the different polishing systems influenced the surface roughness of the Filtek Z350 and Filtek bulk-fill composites. Even lower Ra values were found when using the SOF-Lex and Enhance systems. Between the different composites, Filtek Z350 demonstrated less roughness before the use of burs and diamond paste.

\section{References}

1. Demarco FF, Collares K, Coelho-de-Souza FH, Correa MB, Cenci MS, Moraes RR, et al. Anterior composite restorations: A systematic review on long-term survival and reasons for failure. Dental Materials 2015; 31(10):1214-24. doi: https:// doi.org/10.1016/j.dental.2015.07.005.

2. Costa GDFAD, Fernandes ACBDCJ, Carvalho LADO, de Andrade AC, de Assunção IV, Borges BCD. Effect of additional polishing methods on the physical surface properties of different nanocomposites: SEM and AFM study. Microscopy Res Technique 2018;81(2):1467-73. doi: https://doi.org/10.1002/jemt.23147.
3. Nair VS, Sainudeen S, Padmanabhan P, Vijayashankar LV, Sujathan U, Pillai R. Three-dimensional evaluation of surface roughness of resin composites after finishing and polishing. J Conservative Dent 2016;19(1):91-5. doi:10.4103/09720707.173208.

4. Martinez EM, De Moraes Canedo PM. Avaliação da resistência flexural de resinas compostas convencionais e do sistema bulk-fill. Rev Ciênc Méd Biol 2017;16(3):300-4. doi: http:// dx.doi.org/10.9771/cmbio.v16i3.24403.

5. Magdy NM, Kola MZ, Alqahtani HH, Alqahtani MD, Alghmlas AS. Evaluation of surface roughness of different direct resin-based composites. J Int Soc Preventive Community Dent 2017;7(3):104-9. doi: 10.4103/jisped. JISPCD_72_17.

6. De Carvalho CH, Gonçalves AR, de Sá Brandim A, de Souza WC. Propriedades mecânicas de resinas nanopartículadas e microhíbridas fotoativadas por diferentes fontes de luz. Rev Odontol Brasil Central 2015; 24(71).

7. Pettini F, Corsalini M, Savino MG, Stefanachi G, Di Venere D, Pappalettere D, et al. Roughness analysis on composite materials (microfilled, nanofilled and silorane) after different finishing and polishing procedures. Open Dent J 2015(9):35767. doi: $10.2174 / 1874210601509010357$

8. Benetti AR, Havndrup-Pedersen C, Honoré D, Pedersen MK, Pallesen U. Bulk-fill resin composites: polymerization contraction, depth of cure, and gap formation. Operative Dent 2015;40(2):190-200.

9. De Almeida L, Santin DC, Maran BM, Naufel FS, Schmitt VL. Avaliação do manchamento e da rugosidade superficial de materiais restauradores diretos após diferentes sistemas de polimento: estudo in vitro. Rev Odontol UNESP 2019;48:e20180096. doi: http://dx.doi.org/10.1590/18072577.09618

10. Leprince JG, Palin WM, Vanacker J, Sabbagh J, Devaux J, Leloup G. Physico-mechanical characteristics of commercially available bulk-fill composites. J Dent 2014;42(8):993-1000. doi: https://doi.org/10.1016/j.jdent.2014.05.009

11. Rigo, LC, Bordin D, Fardin VP, Coelho PG, Bromage TG, Reis A, et al. Influence of polishing system on the surface roughness of flowable and regular-viscosity bulk fill composites. Int J Period Restorative Dent 2018;38(4):e79-e86.

12. Ayar MK, Guven ME, Burduroglu HD, Erdemir F. Repair of aged bulk-fill composite with posterior composite: Effect of different surface treatments. J Esthetic Restorative Dent 2018;1-7. doi: https://doi.org/10.1111/jerd.12391

13. De Lacerda LR, Bossardi M, Mitterhofer WJS, de Carvalho FG, Carlo HL, Piva E, et al. New generation bulk-fill resin composites: Effects on mechanical strength and fracture reliability. J Mech Behavior Biomed Mat 2019;96:214-8. doi: https://doi.org/10.1016/j.jmbbm.2019.04.046

14. Shimokawa CAK, Giannini M, Andre CB, Sahadi BO, Faraoni JJ, Palma-Dibb RG, et al. In vitro evaluation of surface properties and wear resistance of conventional and bulk-fill resin-based composites after brushing with a dentifrice. Operative Dent 2019. doi: 10.2341/18-200-L

15. Martins Alves LM, Cardoso da Silva IP, Satomi Kunihira T, Izolani Neto O, Goulart Carvalho Pereira VF, do Reis Goyatá F. Rugosidade e microscopia de força atômica de resinas compostas submetidas a diferentes métodos de polimento. Polímeros Ciênc Tecnol 2013;23(5):661-6. doi: http://dx.doi.org/10.4322/polimeros.2013.053

16. Ferraris F, Conti A. Superficial roughness on composite 
surface, composite enamel and composite dentin junctions after different finishing and polishing procedures. Part I: roughness after treatments with tungsten carbide vs diamond burs. Int J Esthetic Dent 2014;9(1):70-89.

17. Ehrmann, E, Medioni E, Brulat-Bouchard N. Finishing and polishing effects of multiblade burs on the surface texture of 5 resin composites: microhardness and roughness testing. Restorative Dent Endodontics 2019;44(1). doi: https://doi.org/10.5395/rde.2019.44.e1

18. Yadav RD, Raisingani D, Jindal D, Mathur R. A comparative analysis of different finishing and polishing devices on nanofilled, microfilled, and hybrid composite: A scanning electron microscopy and profilometric study. International J Clin Pediatr Dent 2016;9(3):201-8. doi: 10.5005/jpjournals-10005-1364

19. Lainović T, Blažić L, Kukuruzović D, Vilotić M, Ivanišević A, Kakaš D. Effect of diamond paste finishing on surface topography and roughness of dental nanohybrid compositesAFM analysis. Procedia Engineering 2014;69:945-51. doi: https://doi.org/10.1016/j.proeng.2014.03.074

20. Sahbaz C, Bahsi E, Ince B, Bakir EP, Cellik O. Effect of the different finishing and polishing procedures on the surface roughness of three different posterior composite resins. Scanning 2016;38(5):448-54. doi: https://doi. org $/ 10.1002 /$ sca. 21295
21. Lopes IAD, Monteiro PJVC, Mendes JJB, Goncalves JMR, Caldeira FJF. The effect of different finishing and polishing techniques on surface roughness and gloss of two nanocomposites. Saudi Dent J 2018;30(3):197-207. doi: https://doi.org/10.1016/j.sdentj.2018.04.003

22. Gönülol N, Yilmaz F. The effects of finishing and polishing techniques on surface roughness and color stability of nanocomposites. J Dent 2012;40(2):e64-e70. doi: https://doi. org/10.1016/j.jdent.2012.07.005

23. Bittencourt BF, Gomes GM, Trentini FA, Azevedo MRD, Gomes JC, Gomes OMM. Effect of finishing and polishing on surface roughness of composite resins after bleaching. Braz J Oral Scie 2014;13(2):158-62. doi: http:// dx.doi.org/10.1590/1677-3225v13n2a15

24. Alves CB, Giuriato JB, Turbino ML, Oda M. Rugosidade superficial de diferentes resinas compostas comparando sistemas de acabamento e polimento e após a profilaxia com jato de bicarbonato: estudo in vitro. Clin Lab Res Dent 2015;21(1):11-8. doi: https://doi.org/10.11606/issn.23578041.clrd.2015.83527

25. Abzal MS, Rathakrishnan M, Prakash V, Vivekanandhan P, Subbiya A, Sukumaran VG. Evaluation of surface roughness of three different composite resins with three different polishing systems. Journal of conservative dentistry: JCD 2016;19(2):171-4. doi: 10.4103/0972-0707.178703 